\title{
Serum retinol, iron status and body composition of lactating women in Nandi, Kenya
}

Citation for published version (APA):

Ettyang, G. A., van Marken Lichtenbelt, W. D., Oloo, A., \& Saris, W. H. M. (2003). Serum retinol, iron status and body composition of lactating women in Nandi, Kenya. Annals of Nutrition and Metabolism, 47(6), 276-283. https://doi.org/10.1159/000072400

Document status and date:

Published: 01/01/2003

DOI:

10.1159/000072400

Document Version:

Publisher's PDF, also known as Version of record

\section{Please check the document version of this publication:}

- A submitted manuscript is the version of the article upon submission and before peer-review. There can be important differences between the submitted version and the official published version of record.

People interested in the research are advised to contact the author for the final version of the publication, or visit the DOI to the publisher's website.

- The final author version and the galley proof are versions of the publication after peer review.

- The final published version features the final layout of the paper including the volume, issue and page numbers.

Link to publication

\footnotetext{
General rights rights.

- You may freely distribute the URL identifying the publication in the public portal. please follow below link for the End User Agreement:

www.umlib.nl/taverne-license

Take down policy

If you believe that this document breaches copyright please contact us at:

repository@maastrichtuniversity.nl

providing details and we will investigate your claim.
}

Copyright and moral rights for the publications made accessible in the public portal are retained by the authors and/or other copyright owners and it is a condition of accessing publications that users recognise and abide by the legal requirements associated with these

- Users may download and print one copy of any publication from the public portal for the purpose of private study or research.

- You may not further distribute the material or use it for any profit-making activity or commercial gain

If the publication is distributed under the terms of Article $25 \mathrm{fa}$ of the Dutch Copyright Act, indicated by the "Taverne" license above, 


\title{
Serum Retinol, Iron Status and Body Composition of Lactating Women in Nandi, Kenya
}

\author{
G.A. Ettyang ${ }^{a}$ W.D. van Marken Lichtenbelt ${ }^{c}$ A. Oloo ${ }^{b}$ W.H.M. Saris ${ }^{c}$ \\ Departments of aHuman Nutrition and Dietetics, and bepidemiology and Preventive Medicine, FHS, \\ Moi University, Eldoret, Kenya; 'Department of Human Biology, Maastricht University, Maastricht, The Netherlands
}

\section{Key Words}

Hemoglobin · Hematocrit · Serum ferritin · Vitamin A status · Fat free mass · Fat mass · Breast-feeding $\cdot$ Breast milk fat

\begin{abstract}
Background: Maternal vitamin A and iron status was investigated among lactating mothers in a rural community in Kenya. The aim of the study was to establish the prevalence and the relationship of these key nutrients to maternal body composition. Methods: Eighty-eight mothers provided samples of breast milk and blood for determination of breast milk vitamin $A$, serum retinol and ferritin. Estimators of body composition were based on the mother's weight, height and skinfold measurements. Results: A total of $78.1 \%$ women had breast milk retinol $<1.05 \mu \mathrm{mol} / /$ with 38 and $62 \%$ having lactated for a period of $<4$ and $>4$ months, respectively. Prevalence of severely deficient serum retinol $<0.35 \mu \mathrm{mol} / \mathrm{l}$ and ferritin $<12 \mu \mathrm{g} / \mathrm{l}$ was 10 and $37 \%$, respectively. Women with serum ferritin $<12 \mu \mathrm{g} / \mathrm{l}$ had significantly lower average hemoglobin $(p<0.01)$, hematocrit $(p<0.01)$ and serum retinol $(p<0.05)$. Serum retinol of mothers who had lactated for $<4$ months was significantly but negatively correlated with total body fat $(r=-0.40 ; p<0.05)$. With a lactation period of $>4$ months a close relationship was found between serum retinol and hemoglobin $(r=0.26$;
\end{abstract}

\section{KARGER}

Fax +41613061234

E-Mail karger@karger.ch

www.karger.com
(C) 2003 S. Karger AG, Basel

0250-6807/03/0476-0276\$19.50/0

Accessible online at:

www. karger.com/anm $p<0.01)$, serum retinol and serum ferritin $(r=0.20 ; p<$ $0.05)$, and fat free mass significantly but negatively correlated with breast milk fat $(r=-0.27 ; p<0.05)$. Serum retinol in combination with hematocrit significantly affected both maternal hemoglobin $(p<0.01)$ and serum ferritin $(p<0.01)$. Conclusion: A high prevalence of vitamin A and iron deficiency was observed in this group of lactating women. Low levels of fat mass were directly related to these indicators of malnutrition.

Copyright $@ 2003$ S. Karger AG, Basel

\section{Introduction}

Vitamin A and iron deficiency anemia are considered to be among the major nutritional deficiencies in developing countries $[1,2]$. Low weight in combination with small iron stores and low serum retinol levels leads to a risk of depletion and hence malnutrition. Furthermore the additional low concentrations of both serum and breast milk vitamin A put the solely breast-fed child at high risk of low intake of vitamin A [3]. In the national survey of preschool-age children $35 \%$ of this vulnerable group were reported to be vitamin A-deficient [4]. The only small survey done in Machakos indicated that vitamin A deficiency during pregnancy is community-specific [5]. National figures for iron deficiency are not yet available. A survey done on pregnant women has reported 57\%
Ms. Grace Adisa Ettyang

Department of Human Nutrition, Faculty of Health Sciences

Moi University, PO Box 4606

Eldoret (Kenya)

Tel. +254 321 61027, Fax +254 321 33041, E-Mail gaettyang@yahoo.com 
to be anemic [6]. The lactating mother in Kenya has been found to be underweight while living under the constraints of a limited food supply and the demands of hard physical work $[7,8]$

Successive pregnancies and lactation have cumulative effects on specific nutrients [9] and depending on maternal body stores lead to the well-documented maternal depletion syndrome [10]. The key nutrients affected may include vitamin $\mathrm{A}$ and iron, whose requirements are increased during pregnancy and lactation. Vitamin A deficiency may exacerbate iron deficiency anemia [11], and its supplementation to pregnant mothers [12] and children [13] has improved iron status as well as child health [14].

The national survey on household food security reports that $23 \%$ of Kenyans come from households where members of the family are unlikely to meet their minimum energy requirements even if the household concentrated all its spending on food [15]. In these households women frequently enter pregnancy with little or no maternal fat stores [16]. Vitamin A and iron may be a problem of public health significance among all the members of the family including the lactating mothers. Maternal nutrition is of paramount importance if the nutrition and health condition of the child are to be improved [17]. Supplementation with iron or vitamin A tends to target the pregnancy phase of the reproductive cycle. Relying on intervention in the late first trimester or early second trimester of pregnancy may be too late [18]. Information on how and when to intervene is critical and needs to be tailored to meet the unique needs of each target group [19, 20]. This necessitates the identification of communities where both pregnant and lactating mothers may not only be undernourished but are also at risk of vitamin $\mathrm{A}$ and iron deficiency.

The present study was therefore undertaken to investigate the prevalence of vitamin A and iron deficiency anemia among lactating mothers living in a rural community in Kenya. We present the results of a cross-sectional study in which we determined the prevalence of vitamin A and iron deficiency in lactating women in the Kokwet location of Nandi district, Kenya. We also examined whether there is an association between serum retinol, ferritin, breast milk retinol concentrations and body composition.

\section{Materials and Methods}

The study was carried out in December 1998 and January 1999. It involved the examination of 88 normal lactating women aged 1545 years with their breast-feeding children aged between 2 weeks and
15 months from 7 villages in Kokwet location of Nandi district, an area $30 \mathrm{~km}$ southwest of Eldoret Town. The women in this study came from a rural farming community and are considered at risk in relation to low energy and nutrient intake. All the lactating mothers in the 7 villages were identified and visited in their homes and interviewed. In addition to food intake, child health and nutritional status, other variables of interest were maternal body composition, iron and vitamin A status. The study was carried out following the ethical standards of Moi University, Eldoret and with clearance and permission from the Kenyan government.

\section{Anthropometry, Blood and Breast Milk Collection}

Information on age, parity, length of lactation, and interval since last pregnancy was recorded by using a questionnaire. Anthropometric measurements comprising height, weight, mid-upper arm circumference and skinfold thickness were performed and used to determine maternal fat mass and fat free mass [21]. Venous blood samples of about $5 \mathrm{ml}$ were taken and stored on ice for transportation to the laboratory. Serum was separated from blood by centrifugation at $200 \mathrm{~g}$ for $15 \mathrm{~min}$ at room temperature on arrival and samples stored separately at $-20^{\circ} \mathrm{C}$ in the dark. Breast milk was collected from one breast that had not been used to feed the infant for at least $1 \mathrm{~h} \mathrm{[22]}$ and covered and stored in a cool box for transportation to the laboratory. Milk samples were re-homogenized at room temperature and the samples stored separately at $-20^{\circ} \mathrm{C}$ in the dark.

\section{Biochemical Analysis}

Leishman's stain was used to make blood smears, and erythrocyte and leukocyte status of the lactating mothers was determined and cell morphology classified into three categories of normal, mild and moderate. The blood slides were examined for the distribution of macrocytic cells due to vitamin $B_{12}$ or folic acid deficiency, microcytic hypochromic anemia due to iron deficiency and the presence of hypochromic cells. A Coulter counter, model 560 was used to determine hemoglobin $(\mathrm{Hb})$, hematocrit ratio $(\mathrm{Hct})$, mean cell volume (MCV) and red blood cell (RBC) count.

The creamatocrit method as described by Lucas et al. [23] was used to determine breast milk fat and energy concentration: The vitamin A concentration was expressed as a ratio to the fat concentration in percent, i.e. $1.5 \mu \mathrm{mol} / 1$ vitamin A: $5 \%$ fat $=0.3 \mu \mathrm{mol} / \%$ fat $[20$, 22]. Retinol levels in serum and breast milk were assayed using highperformance liquid chromatography. Measurement of serum ferritin (SF) was performed using the enzyme-linked immunosorbent assay (ELISA, Boehringer Mannheim Immundiagnostik, Mannheim, Germany).

Nutritional anemia was assessed by using both $\mathrm{Hb}$ and Hct [24]. The lactating mothers were categorized as having iron deficiency anemia when found with a $\mathrm{Hb}$ of $<12 \mathrm{~g} / \mathrm{dl}$ or a Hct ratio of $<37$. Depletion of iron stores was based on the levels of SF concentration: severe $<12 \mu \mathrm{g} / \mathrm{l}$; marginal $12-29 \mu \mathrm{g} / \mathrm{l}$ and normal $\geq 30 \mu \mathrm{g} / \mathrm{l}$. Vitamin A status was based on serum retinol concentration: deficient, $<0.35 \mu \mathrm{mol} / \mathrm{l}(10 \mu \mathrm{g} / \mathrm{dl})$ and marginal, $<0.70 \mu \mathrm{mol} / \mathrm{l}(20 \mu \mathrm{g} / \mathrm{dl})$. The same cutoff points were used for deficiency in breast milk retinol levels.

\section{Statistical Analyses}

Data were analyzed with the SPSS/PC statistical package (version 9.2 1998). Mean, standard deviations and median were calculated. Independent samples' Student's t test was used to determine the significance of the differences between lactating mothers with normal 
Table 1. Characteristics and biochemical indexes of the lactating women

\begin{tabular}{lcrrr}
\hline & Percentiles & & & \\
\cline { 2 - 5 } & Mean \pm SD & 5 th & 50 th & 95 th \\
\hline Mother's age, years & $27.2 \pm 6.1$ & 18.8 & 28.0 & 38.3 \\
Child's age, months & $7.6 \pm 4.9$ & 1.3 & 6.2 & 15.0 \\
Childs birth weight & $3.4 \pm 0.54$ & 2.5 & 3.4 & 4.2 \\
Children & $3.9 \pm 2.4$ & 1.0 & 3.5 & 8.5 \\
Lactation length, months & $7.8 \pm 4.9$ & 1.3 & 8.2 & 15.0 \\
Height, cm & $161.1 \pm 5.9$ & 150.9 & 161.9 & 171.6 \\
Weight, kg & $56.5 \pm 9.7$ & 42.5 & 55.0 & 76.9 \\
Mid arm circumference & $24.8 \pm 2.7$ & 21.0 & 24.7 & 29.8 \\
Body mass index & $21.7 \pm 3.2$ & 17.2 & 21.4 & 28.0 \\
Body fat, \% & $26.1 \pm 5.4$ & 7.4 & 26.1 & 35.9 \\
Fat free mass, kg & $41.3 \pm 5.1$ & 33.3 & 41.3 & 50.6 \\
Hb, g/dl $(\mathrm{n}=73)$ & $11.9 \pm 1.8$ & 8.9 & 12.3 & 14.8 \\
Hct ratio $(\mathrm{n}=73)$ & $34.9 \pm 3.2$ & 28.7 & 36.0 & 38.8 \\
MCV/l $(\mathrm{n}=69)$ & $81 \pm 7.5$ & 67.0 & 83.0 & 95.0 \\
RBC, $10^{12} / \mathrm{l}(\mathrm{n}=56)$ & $44.6 \pm 3.7$ & 39.1 & 44.3 & 52.5 \\
SF, $\mu \mathrm{g} / \mathrm{l}(\mathrm{n}=67)$ & $21.5 \pm 16.3$ & 4.5 & 15.4 & 50.1 \\
Serum retinol, $\mu$ mol/l $(\mathrm{n}=69)$ & $0.69 \pm 0.26$ & 0.34 & 0.69 & 1.2 \\
Breast milk fat, \% $(\mathrm{n}=68)$ & $4.3 \pm 2.3$ & 1.0 & 4.0 & 9.6 \\
Breast milk retinol, $\mu$ mol/l $(\mathrm{n}=73)$ & $0.90 \pm 0.7$ & 0.23 & 0.70 & 2.84 \\
& & & & \\
& & & &
\end{tabular}

Geometric mean $\pm \mathrm{SD}, \mathrm{n}=88$ except where otherwise noted.
Table 2. Significance of mean values of micronutrients and body composition in lactating mothers with normal and depleted iron stores based on SF levels

\begin{tabular}{lllll}
\hline Variable & Iron stores $^{\mathrm{a}}$ & $\mathrm{n}$ & Mean $\pm \mathrm{SD}$ & p value $^{\mathrm{b}}$ \\
\hline $\mathrm{Hb}, \mathrm{g} / \mathrm{dl}$ & severe depletion & 25 & $10.7 \pm 1.8$ & $<0.01$ \\
& marginal to normal & 42 & $12.6 \pm 1.4$ & \\
$\mathrm{Hct}$ ratio & severe depletion & 25 & $32.6 \pm 3.6$ & $<0.01$ \\
& marginal to normal & 42 & $36.3 \pm 2.1$ & \\
Serum retinol, $\mu \mathrm{mol} / \mathrm{l}$ & severe depletion & 24 & $0.63 \pm 0.15$ & $<0.05$ \\
& marginal to normal & 41 & $0.74 \pm 0.30$ & \\
Breast milk retinol, $\mu \mathrm{mol} / 1 \mathrm{l}$ & severe depletion & 25 & $0.98 \pm 0.90$ & $>0.05$ \\
& marginal to normal & 42 & $0.86 \pm 0.60$ & \\
Body mass index & severe depletion & 25 & $22.3 \pm 2.6$ & $>0.05$ \\
& marginal to normal & 42 & $21.4 \pm 3.7$ & \\
\% body fat & severe depletion & 25 & $27.5 \pm 5.3$ & $>0.05$ \\
& marginal to normal & 42 & $25.3 \pm 5.8$ & \\
Fat free mass, $\mathrm{kg}$ & severe depletion & 25 & $42.0 \pm 4.1$ & $>0.05$ \\
& marginal to normal & 42 & $40.8 \pm 6.1$ & \\
\hline
\end{tabular}

a SF $<12 \mu \mathrm{g} / \mathrm{l}=$ severe depletion; $\mathrm{SF}>12 \mu \mathrm{g} / \mathrm{l}=$ marginal to normal.

${ }^{\mathrm{b}} \mathrm{p}$ value based on $\mathrm{t}$ test for independent samples. and depleted iron stores. The chi-square test was used to compare the difference between proportions of mothers with normal and low serum retinol and ferritin. Pearson's correlation tests were performed to examine the relationships between body composition, serum retinol and measures of iron status. In order to identify individual factors and the combination of factors likely to affect fat stores, iron deficiency anemia and the vitamin A status of the rural lactating mothers, both backward and step multiple regressions were done. $\mathrm{Hb}$ status, SF and percent body fat were treated as dependent variables. Due to a skewed distribution natural log-transformed values were used for SF concentration.

The following predictor variables were used in the multiple regression analyses: maternal: age and parity; child: age and reported birth weight; vitamin A: breast milk fat, breast milk retinol and 
Fig. 1. Maternal iron stores and vitamin A status. Low: SF $<30 \mu \mathrm{g} / \mathrm{l}$, serum retinol $<1.05 \mu \mathrm{mol} / 1$. Normal: $\mathrm{SF}>30 \mu \mathrm{g} / \mathrm{l}$, serum retinol $>1.05 \mu \mathrm{mol} / \mathrm{l}$. Pearson $\chi^{2} \mathrm{p}<0.05$.

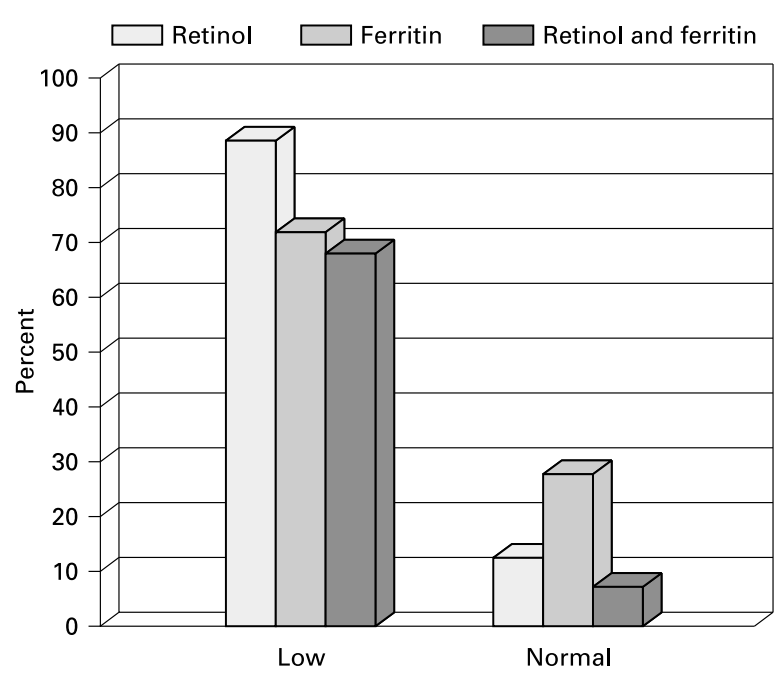

Mild to moderate microcytosis and macrocytosis occurred in 29 and $16 \%$ of the mothers while $35 \%$ of the mothers had mild to moderate hypochromia. Hb status $<12 \mathrm{~g} / \mathrm{dl}$ and Hct ratio $<37$ were found in 43.8 and $69.9 \%$ of the women, respectively. SF concentration was severely deficient $(<12 \mu \mathrm{g} / \mathrm{l})$ in $37 \%$, marginal $(<30 \mathrm{~g} / \mathrm{l})$ in $39 \%$ and adequate $(>30 \mu \mathrm{g} / \mathrm{l})$ in $24 \%$ of the lactating mothers.

Mothers with severely depleted iron stores $(\mathrm{SF}<12$ $\mu \mathrm{g} / \mathrm{l})$ had significantly lower average $\mathrm{Hb}(\mathrm{p}<0.01)$, Hct $(\mathrm{p}<0.01)$ and serum retinol levels $(\mathrm{p}<0.05$, table 2$)$. There was a significant difference $(\mathrm{p}<0.05)$ between mothers (67\%) with low serum retinol $(<1.05 \mu \mathrm{mol} / \mathrm{l})$ and SF $(<30 \mu \mathrm{g} / \mathrm{l})$ and mothers $(7.7 \%)$ with both normal serum retinol $(>1.05 \mu \mathrm{mol} / \mathrm{l})$ and $\mathrm{SF}(>30 \mu \mathrm{g} / \mathrm{l})$ (fig. 1$)$.

Mothers with a lactation period of $<4$ or $>4$ months were 37.7 and $62.3 \%$, respectively. In the early months of lactation ( $<4$ months) serum retinol was significant but negatively correlated with total body fat $(r=-0.40 ; p<$ 0.05 ). Mothers with a longer lactation period had fat free mass that was significant but negatively correlated with breast milk fat $(r=-0.27 ; p<0.05)$. The correlation matrix relating maternal $\mathrm{Hb}$ status as well as SF concentration with Hct, and serum retinol is shown in table 3. Mothers with a lactation period of $<4$ months had a $\mathrm{Hb}$ status that was highly significant and positively correlated with SF $(r=0.46 ; p<0.01)$ and Hct $(r=0.65 ; p<0.01)$. For both $\mathrm{Hb}$ status and SF concentration the correlation coefficients were high and statistically significant for lactation duration of $>4$ months. Serum retinol was highly 
Table 3. Correlation and level of statistical significance of maternal indexes of iron and serum retinol for lactation duration of $<4$ or $>4$ months

\begin{tabular}{|c|c|c|c|c|c|c|c|c|}
\hline & \multicolumn{4}{|c|}{ Lactation $<4$ months $(\mathrm{n}=30)$} & \multicolumn{4}{|c|}{ Lactation $>4$ months $(\mathrm{n}=50)$} \\
\hline & \multicolumn{2}{|l|}{$\mathrm{Hb}$} & \multicolumn{2}{|c|}{ ferritin } & \multicolumn{2}{|l|}{$\mathrm{Hb}$} & \multicolumn{2}{|c|}{ ferritin } \\
\hline & $\mathrm{r}$ & $\mathrm{p}$ & $\mathrm{r}$ & $\mathrm{p}$ & $\mathrm{r}$ & $\mathrm{p}$ & $\mathrm{r}$ & $\mathrm{p}$ \\
\hline $\mathrm{Hb}$ & & & 0.46 & $<0.05$ & & & 0.53 & $<0.01$ \\
\hline Ferritin & 0.46 & $<0.01$ & & & 0.54 & $<0.01$ & & \\
\hline Hct & 0.65 & $<0.01$ & 0.43 & $<0.05$ & 0.77 & $<0.01$ & 0.67 & $<0.01$ \\
\hline Retinol & -0.06 & $>0.05$ & 0.10 & $>0.05$ & 0.26 & $<0.01$ & 0.20 & $<0.05$ \\
\hline
\end{tabular}

Table 4. Coefficients $(\beta)$ and significance levels $(\mathrm{p})$ from multiple regression analyses of $\mathrm{Hb}$ for all mothers and iron store status for mothers with ferritin concentration in serum $<30 \mu \mathrm{g} / 1$ as the dependent variables

\begin{tabular}{|c|c|c|c|c|c|c|c|c|c|c|}
\hline \multirow{2}{*}{$\begin{array}{l}\text { Predictor } \\
\text { variables }\end{array}$} & \multicolumn{5}{|c|}{ Hb status $(n=67)$} & \multicolumn{5}{|c|}{ Ferritin concentration $(<30 \mu \mathrm{g} / \mathrm{l})(\mathrm{n}=51)$} \\
\hline & $\beta$ & $\mathrm{r}$ & $r^{2}$ & $\mathrm{~F}$ & $\mathrm{p}$ & $\beta$ & $\mathrm{r}$ & $\mathrm{r}^{2}$ & $\mathrm{~F}$ & $\mathrm{p}$ \\
\hline Constant & -2.89 & & & & & -22.10 & & & & \\
\hline Hct & 0.43 & 0.74 & 0.54 & 40.0 & $<0.01$ & 1.03 & 0.56 & 0.32 & 17.4 & $<0.01$ \\
\hline Constant & -4.00 & & & & & -27.04 & & & & \\
\hline Hct & 0.42 & 0.77 & 0.60 & 24.7 & $<0.01$ & 1.00 & 0.64 & 0.41 & 12.8 & $<0.01$ \\
\hline Serum retinol & 1.80 & & & & & 8.78 & & & & \\
\hline
\end{tabular}

significant and positively correlated to $\mathrm{Hb}$ status $(\mathrm{r}=0.26$; $\mathrm{p}<0.01)$ and significantly and positively correlated to SF $(\mathrm{r}=0.20 ; \mathrm{p}<0.05)$.

An analysis of variance based on forward step multiple regression is shown in table 4 . Using $\mathrm{Hb}$ and $\mathrm{SF}<30 \mu \mathrm{g} / 1$ as dependent variables, and based on all the predictor variables Hct and serum retinol were highly significant $(\mathrm{p}<0.01)$ factors that explained 60 and $41 \%$ of the total variation in $\mathrm{Hb}$ status and $\mathrm{SF}$ concentrations, respectively. The correlation coefficients of Hct $(0.42 ; 1.00)$ and serum retinol $(1.81 ; 8.78)$, respectively for $\mathrm{Hb}$ status and SF concentrations show a positive direct linear relationship.

Backward multiple regression identified Hct $(p<$ $0.01)$, breast milk fat $(p>0.05)$, serum retinol $(p<0.05)$, body mass index $(p<0.05)$, fat free mass $(p>0.05)$ and percent body fat $(p>0.05)$ as predictor variables able to explain $68 \%$ of the variation in the $\mathrm{Hb}$ status of the lactating women. Hct and serum retinol have a significant effect and need to be taken into account when making predictions and estimates that determine the $\mathrm{Hb}$ status and SF concentrations of lactating mothers.

With regard to maternal body composition, there may be a significant linear relationship between percent body fat, SF and retinol when you take into account maternal age and the child's reported birth weight (table 5). Though these four factors explain $41 \%$ of the variation in percent body fat, except for maternal age, the other three coefficients show a negative direct linear relationship.

\section{Discussion}

The present study explores the relationship between 'serum retinol' and biochemical measures of iron nutriture and breast milk retinol, body composition in a population of lactating mothers in rural Kenya. A large percentage $(73 \%)$ of the Kenyan population still lives in the rural area [15]. Nutritional studies in the country have tended to concentrate on the preschool-age child and to a very small degree on the pregnant mother. Lactating mothers were chosen as the subjects of this study because they are equally vulnerable to the documented vitamin A and iron metabolic interactions. During the reproductive cycle continuous depletion of these nutrients has negative effects on both the health and nutritional status of the mother and the infant. To this we now add the interactions likely to occur in relation to maternal body composition. 
Table 5. Coefficients $(\beta)$ and significance levels (p) from multiple regression analyses of percent body fat as the dependent variable for 88 lactating women

\begin{tabular}{|c|c|c|c|c|c|}
\hline & \multicolumn{5}{|c|}{ Predictor variables } \\
\hline & $\beta$ & $\mathrm{r}$ & $\mathrm{r}^{2}$ & $\mathrm{~F}$ & $\mathrm{p}$ \\
\hline Constant & 38.67 & & & & \\
\hline Child birth weight & -3.52 & 0.34 & 0.12 & 5.48 & $<0.05$ \\
\hline Constant & 49.87 & & & & \\
\hline Child birth weight & -5.18 & 0.47 & 0.22 & 5.64 & $<0.01$ \\
\hline Serum retinol & -7.54 & & & & \\
\hline Constant & 51.54 & & & & \\
\hline Child birth weight & -5.19 & 0.55 & 0.30 & 5.50 & $<0.01$ \\
\hline Serum retinol & -6.91 & & & & \\
\hline $\mathrm{SF}$ & -0.09 & & & & \\
\hline Constant & 41.55 & & & & \\
\hline Child birth weight & -4.61 & 0.64 & 0.41 & 6.69 & $<0.01$ \\
\hline Serum retinol & -6.56 & & & & \\
\hline SF & -0.12 & & & & \\
\hline Age of the mother & 0.30 & & & & \\
\hline
\end{tabular}

The WHO identifies an $\mathrm{Hb}$ level below $12 \mathrm{~g} / \mathrm{dl}$ as being anemic. We found $43.8 \%$ of the lactating mothers anemic by this criterion. This compares with the prevalence of $43 \%$ in nonpregnant women in the developing countries [25]. In a rural area in northern Natal a prevalence of anemia in females aged 6-74 years was found to be 52\% [26]. In Bangladesh Ahmed et al. [27] found a prevalence of $44 \%$ among adolescent female garment factory workers with rural roots. When simple correlation tests were used we observed a highly significant correlation between $\mathrm{Hb}$ and Hct, SF concentration and MCV. This suggests that iron status was likely to be an important determinant of $\mathrm{Hb}$ and hence anemia. On the basis of combined cutoff points for $\mathrm{Hb}$ and $\mathrm{SF}(\mathrm{Hb}<12 \mathrm{~g} / \mathrm{dl}$ and $\mathrm{SF}<12 \mu \mathrm{g} / \mathrm{l}) 27 \%$ of the lactating mothers with a mean $\mathrm{Hb}$ of $9.89 \mathrm{~g} / \mathrm{dl}$ were iron-deficient. Similar relationships have been found in adolescent girls in peri-urban Bangladesh [28]. It was also found that those lactating mothers with depleted iron stores had significantly lower $\mathrm{Hb}$ and Hct compared with the lactating mothers who had SF levels $\geq 12 \mu \mathrm{g} / 1$, reinforcing the impression that anemia in this group of lactating mothers was causally related to iron status. These mothers were also found to have lower serum retinol levels, indicating a possible relationship between vitamin A status and the use of iron for $\mathrm{Hb}$ formation.

A number of population studies have found positive correlations between serum retinol and biochemical indi- cators of iron status $[11,12]$ and supplementation intervention has tended to target pregnant women and children. The results of our study show that even lactating mothers are equally at risk. The $\mathrm{Hb}$ and serum retinol relationship found in this study is similar to the one reported by Suharno [12] for pregnant women in West Java Indonesia. Bloem et al. [29] found that in children aged 1-8 years there was no association with $\mathrm{Hb}$, but an association for serum retinol with transferrin and serum iron. In the lactating mothers studied, high levels of serum retinol were associated with higher levels of $\mathrm{Hb}(\mathrm{r}=0.26)$. Studies done in Bangladesh by Ahmed et al. [30] also showed that adolescent girls with higher $\mathrm{Hb}$ had better serum retinol levels.

Based on the WHO criteria for serum retinol and breast milk vitamin A concentration, the low levels of breast milk retinol and serum retinol identify this group of lactating mothers as being vitamin A-deficient [20]. A high percentage $(88.4 \%)$ of lactating mothers were at risk of vitamin A deficiency with serum retinol values of less than $1.05 \mu \mathrm{mol} / \mathrm{l}$. The average breast milk fat concentration of $1.29 \pm 0.69 \mu \mathrm{mol} / \mathrm{l}$ is below the recommended cutoff value of $1.4 \mu \mathrm{mol} / 1$. In our study $78 \%$ of the infants were breast-fed on breast milk with an estimated vitamin A concentration of $<1.05 \mu \mathrm{mol} / 1$ [20]. A recent analysis by Humphrey and Amy [3] based on data from studies conducted in Thailand by Stoltzfus and Underwood [22] suggests that this low intake puts the breast-fed infant at risk of vitamin A deficiency.

As shown in table 5, maternal fat stores during lactation need to take into account not only the negative effects on birth weight and maternal age but also on serum retinol and ferritin. The lactation phase of the reproductive cycle is energy-demanding. Maternal body composition stores are a proxy for adequacy of energy and protein intake. This in turn may also have an effect on the mother's iron and vitamin A status. There are no previous Kenyan studies that have looked at the relationship between body composition, vitamin A and iron status in lactating mothers. In this study, the occurrence of a negatively significant correlation between serum retinol and fat mass $(\mathrm{r}=-0.040)$ in mothers with a lactation period of $<4$ months indicates a possible initial significant depletion in maternal energy stores.

With a prolonged lactation period of $>4$ months the increase in breast milk fat is at the expense of a decrease in maternal protein reserves $(r=-0.27)$. This may affect not only the concentration of breast milk vitamin A but also the long-term preservation of maternal energy and protein reserves [16]. The data show that in this rural Kenyan 
community, mothers with a low level of fat mass also had a high prevalence of vitamin A and iron deficiency. Among rural Pakistan women maternal nutritional status was evaluated across a full reproductive cycle and it was found that marginally nourished women lost weight during the reproductive cycle concurrent with a positive trend in infant birth weight [31]. A study done on rural Bangladeshi women concludes that the women failed to gain sufficient weight during the last half of pregnancy to maintain body weight during lactation when energy demand is high [32]. Most studies on body composition during lactation have tended to concentrate on changes in body weight without taking into account the micronutrient deficiencies that are likely to occur. Ability to produce breast milk that is adequate to support the normal growth, nutrient stores and development of infants may be compromised when mothers consume poor-quality diets that are low in animal products and in most vitamins. Decades of exclusive support for children's programs have meant neglect of the welfare of the lactating mother. More work is needed to determine the optimal quantity of nutrients needed to replenish maternal stores and restore breast milk concentrations. In this study body composition indices were computed based on skinfold measurements. Use of more accurate methods may reveal a clearer picture of the extent of depletion in maternal energy and protein reserves.

The data show a high prevalence of nutritional anemia and subclinical vitamin A deficiency among these rural lactating mothers. There is also an interaction between serum retinol, ferritin and percent body fat. In the present study we have shown that even in a group of lactating mothers who may appear otherwise well, marginal vitamin A status is likely to compromise iron stores. This makes it imperative to prevent maternal iron and vitamin A deficiency so that the true long-term benefits of these two nutrients are realized for both the mother and the infant. Mothers should be helped to enter their next pregnancy with better iron reserves [33, 34].

In summary, we found in this group of lactating women lower vitamin A and iron stores and that these indicators of malnutrition were related to each other. Changes in dietary intake may be the preferred long-term solution to the problem of maternal vitamin A and iron deficiency. There is a need to include lactating mothers in intervention strategies aimed at improvement of vitamin A and iron status.

\section{Acknowledgments}

This study was supported by the MUNDO Moi University and Maastricht University project. I am grateful for the facilitation role played by the dean, Prof. B.O. Khwa-Otsyula, and the former dean of the Faculty of Health Sciences, Prof. H.N.K. Arap Mengech. I would like to thank the chief and the mothers of Kokwet community and Mr. L.C. Kimile for providing excellent field and laboratory support, and Dr. A.M. Ngindu for fruitful discussions.

\section{References}

1 WHO/OMS: Highlights of Recent Activities in the Context of the World Declaration and Plan of Action for Nutrition. WHO/OMS/95.2. Geneva, World Health Organization, 1995.

2 UNICEF: The State of the World's Children. New York, Oxford University Press, 1995.

3 Humprey JH, Amy LR: Vitamin A supplementation of young children. Lancet 2000;356: 422-424.

4 Ngare DK: Vitamin A deficiency in Kenya. Rep 17th Int Vitamin A Consultative Group Meet, Guatemala, March 18-22, 1996.

5 Kusin JA: Vitamin A status of pregnant and lactating women as assessed by serum levels in Machakos area Kenya. East Afr Med J 1985; 62:476-479

6 Fishman C, Hansch S: Beyond Child Survival: Programme Option to Benefit Infant Nutrition in Sub-Sahara Africa. Washington, Academy for Educational Development, 1995.
7 Mwadime RK: Dietary considerations in designing nutrition intervention programmes in rural areas of Kenya. East Afr Med J 1995; 7 : 442-448.

8 Kigutha HN: Assessment of dietary intakes among rural communities in Africa: Experiences from Kenya. Am J Clin Nutr 1997;65: S1168-S1172.

9 Jeliffe DB, Maddocks I: Ecological malnutrition in the New Guinea Highlands. Clin Paediatr 1964;3:432-428.

10 Winkvist A, Rasmussen KM, Habicht JP: A new definition of maternal depletion syndrome. Am J Public Health 1992;82:691-694.

11 Bloem MW, Wedel M, van Agtmaal M: Vitamin A intervention: Short-term effects of a single, oral massive dose of iron on metabolism. Am J Clin Nutr 1990;51:76-79.

12 Suharno D, West CE, Muhilal, Karyadi D, Hautvast JG: Supplementation with vitamin A and iron for nutritional anaemia in pregnant women in West Java, Indonesia. Lancet 1993; 342:1325-1328.
13 Mejia LA, Chew F: Haematological effect of supplementing anaemic children with vitamin A alone and in combination with iron. Am J Clin Nutr 1988;48:595-600.

14 Muhilal, Permeisih D, Idjradinata YR: Vitamin A-fortified monosodium glutamate and health, growth, and survival of children: A controlled field trial. Am J Clin Nutr 1988;48: 1271-1276.

15 CBS: The First Report on Poverty in Kenya. Incidence and Depth of Poverty, vol 1. Ministry of Planning and National Development, 1998.

16 Shetty PS: Adaptation to low energy intakes: The responses and limits to low intakes in infants, children and adults. Eur J Clin Nutr 1999;53(suppl 1):S14-S33.

17 Underwood BA: Maternal vitamin A status and its importance in infancy and early childhood. Am J Clin Nutr 1994;59(suppl):517S$524 \mathrm{~S}$. 
18 Beard JL: Effectiveness and strategies of iron supplementation during pregnancy. Am J Clin Nutr 2000;71(suppl 5):1288S-1294S.

19 Djoko Suharno, Muhilal: Vitamin A and nutritional anaemia. Food Nutr Bull 1996;17:7-10.

20 WHO: Indicators for Assessing Vitamin A Deficiency and Their Application in Monitoring and Evaluating Intervention Programmes. WHO/NUT/96.10. World Health Organisation, 1996.

21 Gibson R: Principles of Nutritional Assessment. Oxford, Oxford University Press, 1990.

22 Stoltzfus RJ, Underwood B: Breast milk vitamin $\mathrm{A}$ as an indicator of the vitamin A status for women and infants. Bull World Health Organ 1995;73:703-711.

23 Lucas A, Gibbs JAH, Lyster RLJ, Baum JD: Creamatocrit: Simple clinical technique for estimating fat concentration and energy value of human milk. BMJ 1978;i:1018-1020.

24 Cook JD, Finch CA: Assessing iron status of a population. Am J Clin Nutr 1979;32:21152119
25 WHO: The Prevalence of Anaemia in Women: A Tabulation of Available Information, ed 2. Geneva, World Health Organisation, 1992.

26 Mayer FGH, Schutte CHJ, Reinach SG: Anaemia among the inhabitants of a rural area in Northern Natal. S Afr Med J 1985;67:458462.

27 Ahmed F, Hasan N, Kabir Y: Vitamin A deficiency among adolescent female garment factory workers in Bangladesh. Eur J Clin Nutr 1997;51:698-702.

28 Ahmed F, Khan MR, Islam M, Kabir I, Fuchs GJ: Anaemia and iron deficiency among schoolgirls in peri-urban Bangladesh. Eur J Clin Nutr 2000;54:678-683.

29 Bloem M, Wedel M, Egger RJ: Iron metabolism and vitamin A deficiency in children in northeast Thailand. Am J Clin Nutr 1989;50: 332-338.
30 Ahmed F, Khan MR, Karim R, Taj S, Hyderi T, Faruque MO, Margetts BM, Jackson AA: Serum retinol and biochemical measures of iron status in adolescent schoolgirls in urban Bangladesh. Eur J Clin Nutr 1996;50:346351.

31 Winkvist A, Habicht JP, Rasmussen KM: Linking maternal and infant benefits of a nutritional supplement during pregnancy and lactation. Am J Clin Nutr 1998;68:656-661.

32 Alam DS, Van Raaij JM, Hautvast JG, Yunus M, Fuchs GJ: Energy stress during pregnancy and lactation: Consequences for maternal nutrition in rural Bangladesh. Eur J Clin Nutr 2003;57:151-156.

33 Allen LH: Anemia and iron deficiency: Effects on pregnancy outcome. Am J Clin Nutr 2000; 71(suppl):1280S-1284S.

34 Beard JL: Effectiveness and strategies of iron supplementation during pregnancy. Am J Clin Nutr 2000;71(suppl):1288S-1294S. 